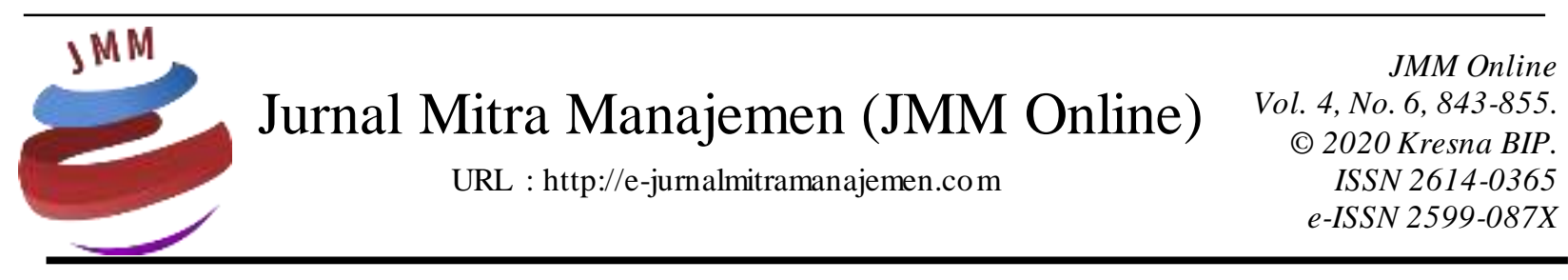

\title{
PENGARUH CORPORATE GOVERNANCE DAN UKURAN PERUSAHAAN TERHADAP INTEGRITAS LAPORAN KEUANGAN
}

\author{
Muhammad Fajar 1), Annisa Nurbaiti 2) \\ Universitas Telkom
}

INFORMASI ARTIKEL

Dikirim : 15 April 2020

Revisi pertama : 11 Juni 2020

Diterima : 16 Juni 2020

Tersedia online : 01 Juli 2020

Kata Kunci: Integritas Laporan
Keuangan, Kepemilikan Manajerial,
Kepemilikan
Komistitusional, Komite Audit,
$\begin{aligned} & \text { Perusahaan } \\ & \text { Independen, }\end{aligned}$

Email : fajarmuhammad271@gmail.com ${ }^{1)}$, annisanurbaiti@telkomuniversity.ac.id ${ }^{2)}$

\section{ABSTRAK}

Integritas laporan keuangan merupakan penyajian laporan keuangan secara benar dan jujur tanpa ada yang disembunyikan. Agar informasi bermanfaat, laporan keuangan juga harus andal, informasi dikatakan andal jik a informasi tersebut tidak menyesatkan, sehingga pengguna laporan keuangan tidak salah dalam pengambilan keputusan.

Tujuan penelitian ini untuk mengetahui pengaruh corporate governance dan ukuran perusahaan terhadap integritas laporan keuangan pada bank umum syariah yang terdaftar di Otoritas Jasa Keuangan tahun 2014-2018.

Metode yang digunakan dalam penelitian ini adalah kuantitatif. Pengambilan sampel dalam penelitian ini menggunakan purposive sampling dan memperoleh 60 unit sampel penelitian. Teknik analisis dalampenelitian in $i$ adalah regresi data panel.

Berdasarkan hasil penelitian, seluruh variabel independen berpengaruh secara simultan terhadap integritas laporan keuangan. Secara parsial kepemilikan institusional, kepemilikan manajerial, komisaris independen tidak berpengaruh terhadap integritas laporan keuangan. Sedangkan komite audit dan ukuran perusahaan berpengaruh secara positif terhadap integritas laporan keuangan. 


\section{PENDAHULUAN \\ Latar Belakang}

Integritas laporan keuangan merupakan penyajian laporan keuangan secara benar dan jujur tanpa ada yang harus disembunyikan. Menurut Qonitin \& Yudowati (2018) menyatakan bahwa laporan keuangan yang berintegritas harus memenuhi dua karakteristik utama laporan keuangan yaitu relevan dan keandalan. Informasi keuangan yang memiliki integritas yang tinggi akan dapat diandalkan karena merupakan suatu penyajian yang jujur sehingga memungkinkan pengguna laporan keuangan bergantung pada informasi tersebut.

Beberapa tahun terakhir banyak perusahaan yang menyajikan laporan keuangan tanpa memikirkan faktor integritas, dapat dikatakan bahwa informasi yang disajikan dalam laporan keuangan tersebut tidak benar dan menyesatkan bagi pengguna laporan keuangan. Kurangnya integritas laporan keuangan menyebabkan banyaknya manipulasi laporan keuangan yang dilakukan oleh perusahaan.

Kasus penyimpangan pada bank syariah terjadi juga di Malaysia. Bank syariah dimana secara asidental internal auditor bank syariah menemukan bahwa bank syariah yang merupakan cabang dari bank konvensional telah melakukan pembiayaan kepada rumah sakit, namun ternyata terjadi transaksi non-syariah compliance pada rumah sakit tersebut. Pembiayaan berlangsung terjadi selama empat tahun, rumah sakit tersebut membayar margin tiap bulan kepada bank syariah artinya karena rumah sakit tersebut pengelolaannya tidak shariah compliance maka secara tidak langsung bank mendapatkan margin pendapatan non-halal dari rumah sakit tersebut. Sehingga pendapatan bank syariah tersebut bercampur dengan pendapatan halal dan non-halal. Sesuai prinsip akuntansi syariah yang full disclosure dan transparansi (www.kompasnia.com).

Laporan keuangan bank syariah wajib menyertakan seluruh transaksi tentang pendapatan halal dan non halal dengan memasukkan catatan tambahan atas laporan keuangan tentang dana penghasilan yang telah digunakan untuk dibagikan kepada nasabah sebagai tanggung jawab bank syariah terhadap masyarakat. Maka, laporan keuangan yang dilaporkan harus memiliki integritas yang tinggi.

\section{Rumusan Masalah} adalah:

Berdasarkan latar belakang yang telah diuraikan maka pertanyaan penelitian ini

1. Bagaimana corporate governance dan ukuran perusahaan dan integritas laporan keuangan pada Bank Umum Syariah yang terdaftar di Otoritas Jasa Keuangan periode 2014-2018?

2. Apakah corporate governance dan ukuran perusahaan berpengaruh secara simultan terhadap integritas laporan keuangan pada Bank Umum Syariah yang terdaftar di Otoritas Jasa Keuangan periode 2014-2018?

3. Apakah kepemilikan manajerial berpengaruh secara parsial terhadap integritas laporan keuangan pada Bank Umum Syariah yang terdaftar di Otoritas Jasa Keuangan periode 2014-2018? 
4. Apakah kepemilikan institusional berpengaruh secara parsial terhadap integritas laporan keuangan pada Bank Umum Syariah yang terdaftar di Otoritas Jasa Keuangan periode 2014-2018?

5. Apakah komite audit berpengaruh secara parsial terhadap integritas laporan keuangan pada Bank Umum Syariah yang terdaftar di Otoritas Jasa Keuangan periode 2014-2018?

6. Apakah komisaris independen berpengaruh secara parsial terhadap integritas laporan keuangan pada Bank Umum Syariah yang terdaftar di Otoritas Jasa Keuangan periode 2014-2018?

7. Apakah ukuran perusahaan berpengaruh secara parsial terhadap integritas laporan keuangan pada Bank Umum Syariah yang terdaftar di Otoritas Jasa Keuangan periode 2014-2018?

\section{Tujuan Penelitian}

Berdasarkan rumusan masalah yang telah dicantumkan diatas, mengenai mekanisme corporate governance dan ukuran perusahaan terhadap integritas laporan keuangan, maka penelitian ini bertujuan:

1. Untuk mengetahui corporate governance, ukuran perusahaan dan integritas laporan keuangan pada perbankan syariah yang terdaftar di Otoritas Jasa Keuangan periode 2014-2018

2. Untuk mengetahui corporate governance, dan ukuran perusahaan berpengaruh secara simultan terhadap integritas laporan keuangan pada Bank Umum Syariah yang terdaftar di Otoritas Jasa Keuangan periode 2014-2018.

3. Untuk mengetahui apakah kepemilikan manajerial berpengaruh secara parsial terhadap integritas laporan keuangan pada Bank Umum Syariah yang terdaftar di Otoritas Jasa Keuangan periode 2014-2018.

4. Untuk mengetahui apakah kepemilikan institusional berpengaruh secara parsial terhadap integritas laporan keuangan pada Bank Umum Syariah yang terdaftar di Otoritas Jasa Keuangan periode 2014-2018.

5. Untuk mengetahui apakah komite audit berpengaruh secara parsial terhadap integritas laporan keuangan pada Bank Umum Syariah yang terdaftar di Otoritas Jasa Keuangan periode 2014-2018.

6. Untuk mengetahui apakah komisaris independen berpengaruh secara parsial terhadap integritas laporan keuangan pada Bank Umum Syariah yang terdaftar di Otoritas Jasa Keuangan periode 2014-2018.

7. Untuk mengetahui apakah ukuran perusahaan berpengaruh secara parsial terhadap integritas laporan keuangan pada Bank Umum Syariah yang terdaftar di Otoritas Jasa Keuangan periode 2014-2018.

\section{KAJIAN PUSTAKA}

\section{Integritas Laporan Keuangan}

Menurut Kemalasarai \& Hapsari (2018) menjelaskan bahwa Integritas laporan keuangan merupakan suatu produk dari standar etika sebagai prinsip moral yang tidak memihak dan jujur dalam mewujudkan penyediaan informasi (laporan keuangan) yang 
secara formal wajib dipublikasikan dengan benar sebagai sarana pertanggung jawaban pihak manajemen terhadap pengelolaan sumber daya pemilik.

\section{Kepemilikan Manajerial}

Menurut Arista (2018) kepemilikan manajerial merupakan pihak manajer yang memiliki saham didalam suatu perusahaan.

\section{Kepemilikan Inistitusional}

Menurut Wulandari \& Budiartha (2014) mengartikan bahwa kepemilikan institusional merupakan persentase jumlah saham pada akhir periode akuntansi yang dimiliki oleh pihak eksternal, seperti lembaga, perusahaan, asuransi, bank atau institusi lain.

\section{Komite Audit}

Menurut Peraturan Otoritas Jasa Keuangan Nomor 55/POJK.04/2015 menjelaskan bahwa komite audit merupakan komite yang dibentuk oleh dan bertanggung jawab kepada dewan komisaris dalam membantu melaksanakan tugas dan fungsi dewan komisaris.

\section{Komisaris Independen}

Menurut Peraturan Otoritas Jasa Keuangan Nomor 55/POJK.03/2016 menjelaskan bahwa komisaris independen adalah Anggota dewan komisaris yang yang tidak memiliki hubungan keuangan, kepengurusan, kepemilikan saham,atau hubungan keluarga dengan dewan komisaris lain dan atau pemegang saham pengendali, atau hubungan dengan bank yang dapat mempengaruhi kemampuan yang bersangkutan untuk bertindak independen.

\section{Ukuran Perusahaan}

Menurut Saksakotama (2014) ukuran perusahaan merupakan "nilai yang menunjukkan besar kecilnya perusahaan. Terdapat instrumen untuk mengukurnya yaitu total penjualan, total aset, jumlah karyawan dan kapitalisasi pasar. 


\section{Gambar 1. Kerangka Pemikiran}

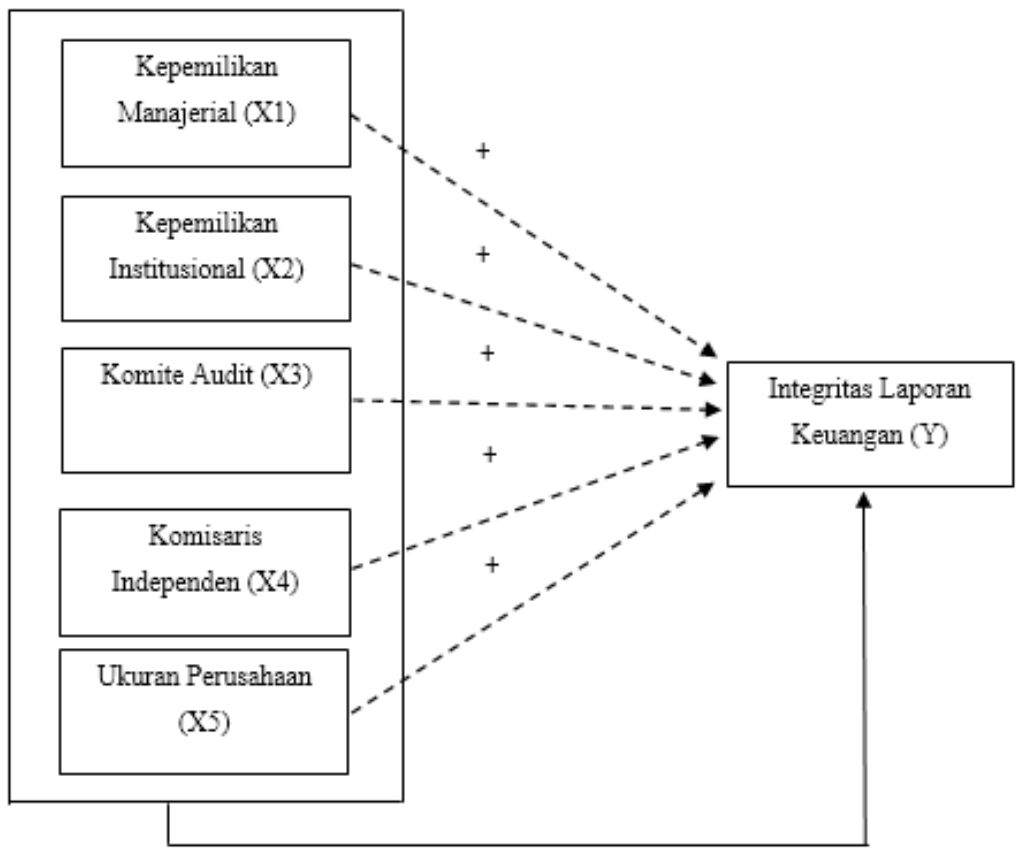

Sumber : Data yang Diolah Penulis (2020)

\section{Hipotesis Penelitian}

H1 : Kepemilikan manajerial, kepemilikan institusional, komite audit, komisaris independen, dan ukuran perusahaan berpengaruh secara simultan terhadap integritas laporan keuangan pada Perbankan Syariah yang terdaftar di Otoritas Jasa Keuangan (OJK) Periode 2014-2018.

H2 : Kepemilikan manajerial berpengaruh positif terhadap integritas laporan keuangan pada Perbankan Syariah yang terdaftar di Otoritas Jasa Keuangan (OJK) Periode 2014-2018.

H3 : Kepemilikan manajerial berpengaruh positif terhadap integritas laporan keuangan pada Perbankan Syariah yang terdaftar di Otoritas Jasa Keuangan (OJK) Periode 2014-2018.

H4 : Komite audit berpengaruh positif terhadap integritas laporan keuangan pada Perbankan Syariah yang terdaftar di Otoritas Jasa Keuangan (OJK) Periode 2014-2018.

H5 : Komisaris independen berpengaruh positif terhadap integritas laporan keuangan pada Perbankan Syariah yang terdaftar di Otoritas Jasa Keuangan (OJK) Periode 2014-2018.

H6 : Ukuran perusahaan berpengaruh positif terhadap integritas laporan keuangan pada Perbankan Syariah yang terdaftar di Otoritas Jasa Keuangan (OJK) Periode 2014-2018. 


\section{METODE PENELITIAN \\ Jenis Penelitian}

Metode yang digunakan dalam penelitian ini adalah metode kauntitatif dan tujuan dalam peneltiain ini yaitu deskriptif dan verifikatif yang bersifat kausalitas.

\section{Waktu, Subjek Penelitian}

Waktu penelitian ini dilaksanakan pada Oktober - Maret 2020, teknik analisis dalam penelitian ini yaitu data panel atau gabungan antara cross section \& time series. Dalam penelitian ini menggunakan subjek yang diteliti yaitu kelompok bank umum syariah yang terdaftar di Otoritas Jasa Keuangan (OJK) periode 2014-2018.

\section{Teknik Pengumpulan Data}

Dalam penelitian ini pengumpulan data didapat dari masing-masing website bank umum syariah dan juga didukung oleh sumber data lain yaitu referensi dari jurnal, artikel, dan hasil penelitian terdahulu.

\section{Teknik Analisis Data}

1. Uji Statistik Deskriptif

2. Uji Multikolineritas

3. Uji Heterokedastisitas

4. Uji Chow

5. Uji Langrange Multiplier

6. Analisis Regresi Data Panel

7. Analisis Koefisien Determinasi

8. Uji Simultan (F)

9. Uji Parsial (T)

\section{HASIL PENELITIAN DAN PEMBAHASAN}

\section{Hasil Penelitian}

Uji Statistik Deksirptif

Tabel 1. Uji Statistik Deskriptif

\begin{tabular}{|l|l|l|l|l|l|l|}
\hline Keterangan & $\begin{array}{c}\text { Kepemilikan } \\
\text { Manaje rial }\end{array}$ & $\begin{array}{c}\text { Kepemilikan } \\
\text { Institusional }\end{array}$ & $\begin{array}{c}\text { Komite } \\
\text { Audit }\end{array}$ & $\begin{array}{c}\text { Komisaris } \\
\text { Independen }\end{array}$ & $\begin{array}{c}\text { Ukuran } \\
\text { Pe rus ahaan }\end{array}$ & $\begin{array}{c}\text { Integritas } \\
\text { Laporan } \\
\text { Keuangan }\end{array}$ \\
\hline Mean & 0,0006 & 0,9732 & 0,4001 & 0,6086 & 29,8956 & $-287,405,861,687$ \\
\hline Maximum & 0,0097 & 1,0000 & 0,6667 & 1,0000 & 32,2195 & $3,719,891,548,000$ \\
\hline Minimum & 0,0000 & 0,7682 & 0,1429 & 0,3333 & 27,2184 & $-5,609,122,485,000$ \\
\hline Std.Dev & 0,0020 & 0,0564 & 0,1113 & 0,1548 & 1,2545 & $1,401,016,660,065$ \\
\hline Observations & 60 & 60 & 60 & 60 & 60 & 60 \\
\hline
\end{tabular}

Sumber : Hasil Penelitian, diolah (2020)

Kesimpulan dari tabel statistic deskriptif yaitu variabel kepemilikan manajerial dan integritas laporan keuangan memiliki data yang bervariasi atau menyebar. Sedangkan variabel kepemilikan institusional, komite audit, komisaris independen, dan ukuran perusahaan memiliki data yang berkelompok. 
Uji Multikolinieritas

\begin{tabular}{lcccrr} 
& \multicolumn{2}{c}{ Tabel 2. Uji Multikolinieritas } \\
& KM & \multicolumn{1}{c}{ INST } & \multicolumn{1}{c}{ KOMA } & \multicolumn{1}{l}{ KOIN } & \multicolumn{1}{l}{ UP } \\
\hline \hline KM & 1.000000 & 0.075576 & -0.006034 & -0.129124 & -0.111982 \\
INST & 0.075576 & 1.000000 & -0.175406 & 0.148440 & -0.251149 \\
KOMA & -0.006034 & -0.175406 & 1.000000 & -0.005837 & 0.323017 \\
KOIN & -0.129124 & 0.148440 & -0.005837 & 1.000000 & 0.005603 \\
UP & -0.111982 & -0.251149 & 0.323017 & 0.005603 & 1.000000
\end{tabular}

Sumber : Hasil Penelitian, diolah (2020)

Dapat disimpulkan dari tabel uji multikolinieritas bahwa antar variabel independen yang digunakan dalam penelitian ini memiliki nilai koefisien antar variabel dibawah 0,8 sehingga dapat disimpulkan bahwa antar variabel independen tidak terjadi multikolinieritas.

\section{Uji Heterokedastisitas}

Tabel 3. Uji Heterokedastisitas

Dependent Variable: RESABS

Method: Panel Least Squares

Date: 02/02/20 Time: 17:34

Sample: 20142018

Periods included: 5

Cross-sections included: 12

Total panel (balanced) observations: 60

\begin{tabular}{|c|c|c|c|}
\hline Variable & Coefficient Std. Error & t-Statistic & Prob. \\
\hline $\mathrm{C}$ & $3.134082 \quad 3.473348$ & 0.902323 & 0.3709 \\
\hline KM & -151.3611100 .7456 & -1.502409 & 0.1388 \\
\hline INST & -2.0092612 .039353 & -0.985244 & 0.3289 \\
\hline KOMA & $0.876046 \quad 2.208625$ & 0.396648 & 0.6932 \\
\hline KOIN & $\begin{array}{lll}-1.405971 & 0.986237\end{array}$ & -1.425591 & 0.1597 \\
\hline UP & $0.001127 \quad 0.002879$ & 0.391496 & 0.6970 \\
\hline
\end{tabular}

Sumber : Hasil Penelitian, diolah (2020)

Dalam penelitian ini uji heterokedastisitas menggunakan uji glejser dan dapat disimpulkan bahwa seluruh nilai probabilitas dalam setiap variabel $>0,05$ maka penelitian ini tidak terjadi heterokedastisitas. 


\section{Uji Chow}

Redundant Fixed Effects Tests

Tabel 4. Uji Chow

Equation: Untitled

Test cross-section fixed effects

\begin{tabular}{llll}
\hline \hline Effects Test & Statistic & d.f. & Prob. \\
\hline \hline Cross-section F & 0.601417 & $(11,43)$ & 0.8170 \\
Cross-section Chi-square & 8.586295 & 11 & 0.6600 \\
\hline \hline
\end{tabular}

Sumber : Hasil Penelitian, diolah (2020)

Berdasarkan tabel tersebut diperoleh nilai Probability ( $p$-value) cross-section Chi-square sebesar 0,6600 >0,05 dengan taraf signifikansi 5\%. Berdasarkan hasil tersebut maka $\mathrm{H}_{0}$ diterima atau penelitian ini menggunakan metode common effect. Selanjutnya dilakukan pengujian antara metode common effect atau random effect menggunakan uji Langrange Multiplier.

\section{Uji Langrange Multiplier}

Tabel 5. Uji Langrange Multiplier

Lagrange multiplier (LM) test for panel data

Date: 01/31/20 Time: 18:01

Sample: 20142018

Total panel observations: 60

Probability in ()

\begin{tabular}{|c|c|c|c|}
\hline $\begin{array}{l}\text { Null (no } \\
\text { effect) } \\
\text { Alternative }\end{array}$ & $\begin{array}{l}\text { Cross-sectio } \\
\text { One-sided }\end{array}$ & $\begin{array}{l}\text { Period } \\
\text { One-sided }\end{array}$ & Both \\
\hline Breusch-Pagan & $\begin{array}{l}1.640406 \\
(0.2003)\end{array}$ & $\begin{array}{l}0.665100 \\
(0.4148)\end{array}$ & $\begin{array}{c}2.305507 \\
(0.1289)\end{array}$ \\
\hline Honda & $\begin{array}{l}-1.280783 \\
(0.8999)\end{array}$ & $\begin{array}{l}-0.815537 \\
(0.7926)\end{array}$ & $\begin{array}{l}-1.482322 \\
(0.9309)\end{array}$ \\
\hline King-Wu & $\begin{array}{l}-1.280783 \\
(0.8999)\end{array}$ & $\begin{array}{l}-0.815537 \\
(0.7926)\end{array}$ & $\begin{array}{l}-1.359778 \\
(0.9130)\end{array}$ \\
\hline GHM & $\begin{array}{l}-- \\
--\end{array}$ & $\begin{array}{l}-- \\
--\end{array}$ & $\begin{array}{c}0.000000 \\
(0.7500)\end{array}$ \\
\hline
\end{tabular}

Sumber : Hasil Penelitian, diolah (2020)

Berdasarkan tabel diatas, hasil uji Langrange Multiplier diperoleh nilai probabilitas cross section Breusch-Pagan sebesar 0,2003 lebih besar dari tarif signifikansi $5 \%$ yang artinya pengambilan keputusan $\mathrm{H}_{0}$ diterima atau penelitian ini menggunakan metode common effect. 


\section{Analisis Regresi Data Panel}

Berdasarkan pengujian yang telah dilakukan maka hasil metode yang baik digunakan dalam penelitian ini adalah model common effect. Berikut tabel common effect :

Dependent Variable: Y

\section{Tabel 6. Common Effect Model}

Method: Panel Least Squares

Date: 01/31/20 Time: 11:28

Sample: 20142018

Periods included: 5

Cross-sections included: 12

Total panel (balanced) observations: 60

\begin{tabular}{lllll}
\hline \hline Variable & \multicolumn{1}{l}{ Coefficient } & Std. Error & t-Statistic & Prob. \\
\hline \hline C & $-2.49 \mathrm{E}+25$ & $1.04 \mathrm{E}+25$ & -2.394569 & 0.0201 \\
KM & $-1.63 \mathrm{E}+26$ & $3.02 \mathrm{E}+26$ & -0.539307 & 0.5919 \\
INST & $2.26 \mathrm{E}+23$ & $6.11 \mathrm{E}+24$ & 0.037014 & 0.9706 \\
KOMA & $1.43 \mathrm{E}+25$ & $6.61 \mathrm{E}+24$ & 2.164900 & 0.0348 \\
KOIN & $-1.98 \mathrm{E}+24$ & $2.95 \mathrm{E}+24$ & -0.671228 & 0.5049 \\
UP & $2.80 \mathrm{E}+22$ & $8.62 \mathrm{E}+21$ & 3.253510 & 0.0020 \\
\hline \hline R-squared & 0.308202 & Mean dependent var & $2.01 \mathrm{E}+24$ \\
Adjusted R-squared & 0.244147 & S.D. dependent var & $5.28 \mathrm{E}+24$ \\
S.E. of regression & $4.59 \mathrm{E}+24$ & Akaike info criterion & 116.5027 \\
Sum squared resid & $1.14 \mathrm{E}+51$ & Schwarz criterion & 116.7121 \\
Log likelihood & -3489.080 & Hannan-Quinn criter. & 116.5846 \\
F-statistic & 4.811503 & Durbin-Watson stat & 1.448251 \\
Prob(F-statistic) & 0.001039 & & & \\
\hline \hline
\end{tabular}

Sumber : Hasil Penelitian, diolah (2020)

CONNAC $=-2.49 \mathrm{E}+25-1.63 \mathrm{E}+26 \mathrm{KM}+2.26+23 \mathrm{INST}+1.43 \mathrm{E}+25$

KOMA - 1.98E+24 + 2.80E+22 UP

Berdasarkan hasil pengujian diatas, dapat diketahui persamaan regresi data panel dalam penelitian ini adalah sebagai berikut:

1. Koefisien intersep sebesar $-2.49 \mathrm{E}+25$ yang berarti apabila variabel kepemilikan manajerial, kepemilikan institusional, komite audit, komisaris independen, dan ukuran perusahaan, maka integritas laporan keuangan akan naik

2. Koefisien variabel kepemilikan manajerial sebesar $-1.63 \mathrm{E}+26$ yang berarti apabila terjadi peningkatan kepemilikan manajerial 1 satuan dan variabel lainnya konstan, maka integritas laporan keuangan akan mengalami penurunan sebesar $-1.63 \mathrm{E}+26$ satuan.

3. Koefisien variabel kepemilikan institusional sebesar $2.26 \mathrm{E}+23$ yang berarti apabila terjadi peningkatan kepemilikan institusional 1 satuan dan variabel lainnya konstan, maka integritas laporan keuangan akan mengalami peningkatan sebesar 2.26E+23. 
4. Koefisien variabel komite audit sebesar $1.43 \mathrm{E}+25$ yang berarti apabila terjadi peningkatan komite audit 1 satuan dan variabel lainnya konstan, maka integritas laporan kuangan akan mengalami peningkatan sebesra $1.43 \mathrm{E}+25$.

5. Koefisien variabel komisaris independen sebesar $-1.98 \mathrm{E}+24$ yang berarti apabila terjadi peningkatan komisaris independen 1 satuan dan variabel konstan, maka integritas laporan keuangan akan mengalami penurunan sebesar -1.98E+24 satuan.

6. Koefisien variabel ukuran perusahaan sebesar $2.80 \mathrm{E}+22$ yang berarti apabila tejadi peningkatan ukuran perusahaan 1 satua dan variabel konstan, maka integritas laporan keuangan mengalami peningkatan $2.280 \mathrm{E}+22$.

\section{Analisis Koefisien Determinasi}

Tabel 7. Analaisis Koefisien Determinasi dan Uji Simultan

\begin{tabular}{llll}
\hline \hline R-squared & 0.308202 & Mean dependent var & $2.01 \mathrm{E}+24$ \\
Adjusted R-squared & 0.244147 & S.D. dependent var & $5.28 \mathrm{E}+24$ \\
S.E. of regression & $4.59 \mathrm{E}+24$ & Akaike info criterion & 116.5027 \\
Sum squared resid & $1.14 \mathrm{E}+51$ & Schwarz criterion & 116.7121 \\
Log likelihood & -3489.080 & Hannan-Quinn criter. & 116.5846 \\
F-statistic & 4.811503 & Durbin-Watson stat & 1.448251 \\
Prob(F-statistic) & 0.001039 & & \\
\hline \hline
\end{tabular}

Sumber : Hasil Penelitian, diolah (2020)

Berdasarkan nilai Adjusted R-squared yang diperoleh sebesar 0,244147. Hal ini juga mengidentifikasi bahwa variabel independen dalam penelitian ini mampu menjelaskan variabel dependen sebesar $24 \%$ dan sisanya $76 \%$ dijelaskan oleh variabel lain diluar penelitian.

\section{Uji Simultan (Uji F)}

Berdasarkan tabel diatas dapat dilihat bahwa nilai prob (F-statistic) adalah sebesar 0,001039 atau lebih kecil dari 0,05 artinya, variabel kepemilikan manajerial, kepemilikan institusional, komite audit, komisaris independen, dan ukuran perusahaan secara simultan berpengaruh signifikan terhadap integritas laporan keuangan.

\section{Uji Parsial (Uji T)}

Method: Panel Least Squares

\section{Tabel 8. Uji Parsial}

Date: 02/02/20 Time: 17:32

Sample: 20142018

Periods included: 5

Cross-sections included: 12

Total panel (balanced) observations: 60

\begin{tabular}{|c|c|c|c|}
\hline Variable & Coefficient Std. Error & $\mathrm{t}$-Statistic & Prob. \\
\hline $\mathrm{C}$ & $-2.49 \mathrm{E}+25 \quad 1.04 \mathrm{E}+25$ & -2.394569 & 0.0201 \\
\hline KM & $-1.63 \mathrm{E}+263.02 \mathrm{E}+26$ & -0.539307 & 0.5919 \\
\hline
\end{tabular}

Muhammad Fajar ${ }^{1)}$, Annisa Nurbaiti ${ }^{2)}$ 


\section{Lanjutan Tabel 8. Uji Parsial}

$\begin{array}{lllll}\text { INST } & 2.26 \mathrm{E}+23 & 6.11 \mathrm{E}+24 & 0.037014 & 0.9706 \\ \text { KOMA } & 1.43 \mathrm{E}+25 & 6.61 \mathrm{E}+24 & 2.164900 & 0.0348 \\ \text { KOIN } & -1.98 \mathrm{E}+24 & 2.95 \mathrm{E}+24 & -0.671228 & 0.5049 \\ \text { UP } & 2.80 \mathrm{E}+22 & 8.62 \mathrm{E}+21 & 3.253510 & 0.0020\end{array}$

Sumber : Hasil Penelitian, diolah (2020)

berikut:

Berdasarkan hasil uji statistik t pada tabel 4.14 maka dapat disimpulkan sebagai

1. Nilai probability (t-statistic) kepemilikan manajerial adalah 0,5919. Nilai tersebut menunjukkan bahwa 0,5919 >0,05, dengan koefisien -1.63E+26. Maka dapat disimpulkan bahwa $\mathrm{HO}_{2}$ diterima sehingga kepemilikan manajerial secara parsial tidak berpengaruh terhadap integritas laporan keuangan.

2. Nilai probability (t-statistic) kepemilikan institusional adalah 0.9706. Nilai tersebut menunjukkan bahwa 0,9706>0,05, dengan koefisien 2.26E+23. Maka dapat disimpulkan bahwa $\mathrm{HO}_{3}$ diterima sehingga kepemilikan institusional secara parsial tidak berpengaruh terhadap integritas laporan keuangan.

3. Nilai probability (t-statistic) komite audit adalah 0,0348. Nilai tersebut menunjukkan bahwa $0,0348<0,05$ dengan koefisien 1.43E+25. Maka dapat disimpulkan bahwa $\mathrm{HO}_{4}$ ditolak sehingga komite audit secara parsial berpengaruh terhadap integritas laporan keuangan dengan arah positif.

4. Nilai probability (t-statistic) komisaris independen adalah 0,5049. Nilai tersebut menunjukkan bahwa 0,5049>0,05 dengan koefisien -1.98E+24. Maka dapat disimpulkan bahwa $\mathrm{H}_{5}$ diterima sehingga komisaris independen secara parsial tidak berpengaruh terhadap integritas laporan keuangan.

5. Nilai probability (t-statistic) ukuran perusahaan adalah 0,0020. Nilai tersebut menunjukkan bahwa $0,0020<0,05$ dengan koefisien 2.80E+22. Maka dapat disimpulkan bahwa $\mathrm{H}_{6}$ ditolak sehingga ukuran perusahaan secara parsial berpengaruh terhadap integritas laporan keuangan dengan arah positif.

\section{KESIMPULAN DAN SARAN}

\section{Kesimpulan}

Berdasarkan hasil penelitian dan pembahasan mengenai "Pengaruh Corporate governance dan Ukuran Perusahaan Terhadap Integritas Laporan Keuangan (Studi pada Bank UmumSyariah yang Terdaftar di Otoritas Jasa Keuangan Periode 20142018)", dengan 12 sampel bank umum syariah dalam kurun waktu 5 tahun sehingga didapatkan 60 unit sampel yang digunakan didalam penelitian ini. Berdasarkan hasil analisis deskriptif dan pengujian menggunakan metode data panel, maka diperoleh kesimpulan sebagai berikut:

1. Kepemilikan Manajerial, Kepemilikan Institusional, Komite Audit, Komisaris Independen, dan Ukuran Perusahaan berpengaruh secara simultan terhadap Integritas Laporan Keuangan pada bank umum syariah yang terdaftar di Otoritas Jasa Keuangan periode 2014-2018. 
2. Kepemilikan manajerial tidak berpengaruh secara parsial terhadap integritas laporan keuangan pada bank umum syariah yang tedaftar di Otoritas Jasa Keuangan periode 2014-2018.

3. Kepemilikan institusional tidak berpengaruh secara parsial terhadap integritas laporan keuangan pada bank umum syariah yang tedaftar di Otoritas Jasa Keuangan periode 2014-2018.

4. Komite audit berpengaruh secara parsial dengan arah positif terhadap integritas laporan keuangan pada bank umum syariah yang tedaftar di Otoritas Jasa Keuangan periode 2014-2018.

5. Komisaris independen tidak berpengaruh secara parsial terhadap integritas laporan keuangan pada bank umum syariah yang tedaftar di Otoritas Jasa Keuangan periode 2014-2018.

6. Ukuran perusahaan berpengaruh secara parsial dengan arah positif terhadap integritas laporan keuangan pada bank umum syariah yang tedaftar di Otoritas Jasa Keuangan periode 2014-2018.

\section{Saran}

\section{Bagi Pihak Akademisi}

Disarankan penelitian ini menjadi referensi untuk penelitian selanjutnya dan penelitian ini menjadi pengetahuan tambahan tentang pengaruh corporate governance dan ukuran perusahaan terhadap integritas laporan keuangan.

2. Bagi Penelitian Selanjutnya

Berdasarkan hasil yang didapat dalam penelitian ini, peneliti selanjutnya disarankan dapat menambah sampel penelitian, atau menggunakan objek penelitian lain yang tidak hanya bank umum syariah yang terdafrtar di Otoritas Jasa Keuangan sehingga dapat lebih menjelaskan tingkat integritas laporan keuangan perusahaan. Peneliti selanjutnya juga disarankan menambah variabel lain yang diprediksi dapat mempengaruhi integritas laporan keuangan.

3. Bagi perusahaan

Melaui penelitian ini diharapkan dapat meningkatkan tugas komite audit khususnya dalam mengawasi penyajian laporan keuangan sehingga laporan keuangan perusahaan yang dihasilkan memiliki integritas tinggi. Dan untuk bank umum syariah yang memiliki ukuran perusahaan besar atau kecil harus terus meningkatkan integritas laporan keuangan karena pihak eksternal seperti masyarakat atau pemerintah menyoroti kinerja perusahaan, dengan demikian laporan keuangan yang disajikan harus memiliki integritas yang tinggi.

4. Bagi investor

Melalui penelitian ini diharapkan menjadi suatu gambaran atau mengetahui faktor-faktor yang dapat menyebabkan perusahaan tidak memiliki integritas laporan keuangan. Pihak investor juga disarankan agar mencari informasi tentang perusahaan yang ingin di investasikan sehingga pihak investor akan mendapatkan keuntungan yang optimal dan juga dapat meminimalisir kerugian. 


\section{DAFTAR PUSTAKA}

Arista, S. 2018. Pengaruh Struktur Corporate governance dan Audit Tenure Terhadap Integritas Laporan Keuangan. Akuntabilitas: Jurnal Penelitian dan Pengembangan Akuntansi, Vol.12 No.2,81.

Kemalasari, H. A., \& Hapsari, D. W. 2018. Analisis Pengaruh Struktur Corporate governance dan Audit Tenure Terhadap Integritas Laporan Keuangan. Vol. 5, No. 3 , ISSN: 2355-9357, 3323-3329.

Kompasnia.com. Isu Auditing Tentang Perkembangan Bank Syariah. Tersedia www.kompasiana.com

POJK Nomor.55/PJOK.03/2016, Penerapan Tata Kelola Bagi Bank Umum . dari www.ojk.go.id

POJK Nomor 55/POJK.04/2015. Pembentukan dan Pedoman Pelaksanaan Kerja Komite Audit

Saksakotama, P. H. 2014. Determinan Integritas Laporan Keuangan Perusahaan Manufaktur di Indonesia. Diponegoro Journal of Accounting, Volume 3, Nomor 2, ISSN (Online): 2337-3806, 1-13.

Wulandari, N., \& Budiartha, I. K. 2014. Pengaruh Struktur Kepemilkan dan Komite Audit, Komisaris Independen dan Dewan Direksi Terhadap Integritas Laporan Keuangan. Vol.7, No.3, ISSN: 2302-8556, 574-586. 